\title{
Polar phospholipids from bovine endogenously oxidized low density lipoprotein interfere with follicular thecal function
}

\author{
B Löhrke, T Viergutz and B Krüger ${ }^{1}$ \\ Unit of Reproductive Biology, Research Institute for the Biology of Farm Animals, Dummerstorf, Germany \\ ${ }^{1}$ Faculty of Medicine, Unit of Medical Biology, University of Rostock, Germany \\ (Requests for offprints should be addressed to T Viergutz; Email: viergutz@ fbn-dummerstorf.de)
}

\begin{abstract}
The role of endogenously oxidized low density lipoprotein (oxLDL) in follicular steroidogenic regulation is unknown. Information may be important in order to elucidate ovulatory dysregulation in disordered lipid metabolism. To obtain specific data, we studied the effect of polar phospholipids (PL) isolated from oxLDL with different endogenous levels of lipohydroperoxides (LHP) on the thecal expression of mRNA encoding steroidogenic enzymes and cyclooxygenase 2 (COX-2), and on the thecal production of superoxide and progesterone. Large (preovulatory) bovine follicles were used and analyses of thecal fragments from single follicles were performed by radioimmunoassays, chemiluminescence assays and quantitative RT-PCR. Basal concentration of mRNA for several lipoprotein receptors exceeded by about 10-times the basal level of mRNA encoding steroidogenic enzymes, suggesting that preovulatory theca receptors may favour uptake of oxLDL. PL (5-11 pmol phosphorus $/ \mathrm{ml}$ ) decreased (up to 0.5 -times the control) progesterone synthesis, production of superoxide and levels of P450 cholesterol side chain cleavage (P450 scc), $3 \beta$-hydroxysteroid dehydrogenase and COX-2 mRNA. Abundance of COX-2 transcripts in thecal tissue incubated with forskolin depended on the progesterone/17 $\beta$-oestradiol ratio of the follicle fluid, i.e. the previous microenvironment in vivo. PL effects were mimicked by the platelet-activating factor (PAF). WEB 2086, a PAF receptor blocker, did not always abolish these responses, suggesting that the effects were not mediated solely by this receptor. PAF interfered dose-dependently with $\mathrm{LH}$-induced responses, indicating interference with $\mathrm{LH}$ signalling. PL from mildly oxidized LDL $(0.5 \mathrm{nmol} / \mathrm{ml} \mathrm{LHP})$ tended to exert greater effects than PL from oxLDL containing $1.5 \mathrm{nmol} / \mathrm{ml}$ LHP. In consideration of the known physiologic role of progesterone, COX-2 and possibly superoxide, these results provide evidence for a potential of PL from oxLDL to induce ovulatory dysregulation and suggest that the extent of the LDL oxidation seems to be important for interfering with thecal responses to the preovulatory $\mathrm{LH}$ surge.
\end{abstract}

Journal of Molecular Endocrinology (2005) 35, 531-545

\section{Introduction}

Mammalian follicles develop into an ovulatory stage due to the preovulatory surge of luteinizing hormone (LH). The LH surge induces an intense synthesis of progesterone in follicular thecal and granulosal layers, requiring a supply of serum lipoproteins as steroidogenic substrates in some mammalian species (Carroll et al. 1992, Brannian et al. 1995). Steroidogenic tissue is capable of utilizing circulating lipids via expression of diverse ligands and receptors (Umans et al. 1999, Argov et al. 2004). Progesterone possesses anti-mitogenic and anti-apoptotic properties that are mediated via progesterone receptors (Peluso \& Pappalardo 1998, Quirk et al. 2004). Inhibitors of progesterone synthesis block ovulation, and the absence of progesterone receptors prevents release of the oocyte, leading to complete infertility in mice (Lydon et al. 1996). Stimulation of follicular progesterone synthesis is brought about via numerous pathways. The preovulatory LH surge elevates the progesterone level of the follicular fluid mainly through a cAMP-protein kinase A (PKA) signalling towards nuclear steroidogenic transcription factors that stimulate expression of thecal and granulosal steroidogenic enzymes (Moore et al. 1990, Mamluk et al. 1998).

Another pathway includes oocyte-somatic cell interactions (Elvin et al. 2000). Oocytes secrete factors, such as the growth differentiation factor-9, that stimulates progesterone synthesis in both granulosa cells, which line the follicle wall, and granulosa-cumulus cells, which are closest to the oocyte. Granulosa-cumulus cells do not express LH receptors. Their preovulatory expansion and increase in progesterone production is mediated through a prostaglandin (PG) $\mathrm{E}_{2}-\mathrm{PGE}_{2}$ receptor pathway. This pathway requires $\mathrm{LH}$ surge-induced transcription of cyclooxygenase-2 (COX-2) (Wu \& Wiltbank 2002) that is closely connected with COX-2 protein expression (Elvin et al. 2000, Sirois 1994, Sirois et al. 2004). The COX-2 enzyme activity is rate limiting for prostaglandin synthesis from arachidonic acid released from phospholipids by A2-phospholipases (Smith et al. 2000). The 
COX-2 activity has an absolute requirement for hydroperoxides including alkyl hydroperoxides (Smith et al. 1996). They are generated by strong oxidants that arise from very reactive superoxide anions with other radicals. The LH surge appears also to induce the ovulatory process via interconnected cyclooxygenase and lipoxygenase pathways (Mikuni et al. 1998). These activities can generate oxylipids, such as oxy and epoxy eicosatrienoic acids and oxidized forms of phospholipids, including platelet-activating factor (PAF)-like compounds, all present in the follicular fluid (Lopez Bernal et al. 1992, Narahara et al. 1996, Newman et al. 2004).

Together with the progesterone-progesterone receptor pathway, these activities have been implicated in an increase in follicular blood flow, vascularization, vascular permeability, degradation of the follicle wall matrix by induction of proteolytic enzymes, contraction of follicular thecal smooth muscle, oocyte maturation by superoxide anions, cumulus expansion, granulosa cell differentiation into the luteal stage, follicle rupture and capture of the cumulus-oocyte complex by the fimbria of the oviduct (Robker \& Richards 1998, Tsafriri \& Reich 1999, Behrman et al. 2001, Jo et al. 2002).

However, lipids undergo oxidation not only within the follicle. An uptake of circulatory lipids is likely to involve lipoproteins oxidized by tissues with high aerobic metabolism, including liver and vascular endothelium with phospholipids of low density lipoprotein (LDL) as a major target. Then, LDL and its phospholipids change their bioactivity (Heery et al. 1995, Marathe et al. 1999, Löhrke et al. 2005a). Thecal vascularization and vascular permeability increase during preovulatory development, and preovulatory follicles have been reported to contain LDL and high density lipoprotein (HDL) (Simpson et al. 1980, Volpe et al. 1991, Jaspard et al. 1997). These lipoproteins have been shown to support synthesis of progesterone by supplying cholesterol from LDL (Bao et al. 1995) but also by cholesterol-dependent and -independent actions of HDL (Azhar et al. 1998, Ragoobir et al. 2002). Follicle cells express receptors of the LDL superfamily, including very low density lipoprotein (VLDL) receptors, LDL receptors and lipoprotein receptor-related protein (LRP) receptors (Argov et al. 2004). The uptake of LDL is mediated via an endocytotic pathway (Golos et al. 1986) and the a2-macroglobulin receptor (Chu \& Pizzo 1994, Ireland et al. 2004). The uptake of lipoprotein particle remnants and HDL is mediated via the scavenger receptor, class B, type I and LRP receptors (Acton et al. 1996, Reaven et al. 1998, Argov et al. 2004). While intact LDL is known to stimulate luteal steroidogenesis (Pate \& Condon 1989, Brannian et al. 1995), oxidatively modified LDL (oxLDL) prepared in a laboratory setting has been reported to inhibit luteal progesterone production (Carroll et al. 1992). Anti-steroidogenic and anti-gonadotrophic activities have been observed also for synthetic alkyl hydro- peroxides (Kodaman et al. 1994). In turn, the level of circulating oxLDL increases in dairy cows with increasing yield whereas no correlation was observed with the oxidized state of VLDL (Löhrke et al. 2005a). However, the role of endogenously oxidized circulating lipids in the ovulatory process of single-ovulating species with follicular waves, such as human and cattle, is unknown. Thecal vascularization during the preovulatory stage may favour exposure to circulatory oxLDL. Moreover, there is a relative paucity of information on the local regulatory factors affecting theca function (Glister et al. 2005). Therefore, experiments were designed to investigate the thecal response of maturing bovine follicles to phospholipids from endogenous oxLDL while testing the hypothesis that such lipids interfere with essential components of the ovulatory process.

\section{Materials and methods}

\section{Materials}

Cloprostenol and depherelin were purchased from Veyx Pharma (Schwarzenborn, Germany), antibodies from Miltenyi (Bergisch-Gladbach, Germany), SYBR gold from MoBiTec (Göttingen, Germany), the lipohydroperoxide assay kit from Alexis Biochemicals (Grünberg, Germany), and the RNA extraction kit from Invitek (Berlin, Germany). Oligonucleotides were synthesised by TIB Mol (Berlin, Germany), and the iScript cDNA synthesis kit and iQ-SYBR green supermix were obtained from BIO-RAD (München, Germany). Organic solvents were from Roth (Karlsruhe, Germany), enzymes from Serva (Heidelberg, Germany), and culture plates from Greiner (Frinkenhausen, Germany). Molecular mass standards were from Roth and Fermantas (StLeon-Rot, Germany). All other chemicals and biochemicals were from Sigma (Taufkirchen, Germany).

\section{Procedures to isolate mature follicles}

Five cyclic Holstein heifers (2-2.5 years old, $528 \pm 31 \mathrm{~kg}$ in weight) were treated on day $9 \pm 1$ of the oestrous cycle with a luteolytic dose of the $\mathrm{PGF}_{2 \alpha}$ analogue cloprostenol $(0.5 \mathrm{mg} / 2 \mathrm{ml}), 58 \mathrm{~h}$ after the administration of an analogue of the gonadotrophin releasing hormone $(\mathrm{GnRH})$ depherelin - Gonavet $(100 \mu \mathrm{g} / 2 \mathrm{ml})$ to induce the LH surge. Evidence for a comparable response among Holstein cows (with a similar age and weight) was obtained by a parallel experiment (Schneider et al. 2002), indicating a circulatory LH concentration of $60 \pm 15 \mathrm{ng} / \mathrm{ml}(n=6)$ which peaked $2 \mathrm{~h}$ post $\mathrm{GnRH}$ with a decline to about $45 \% 2 \mathrm{~h}$ after the peak and then to baseline values of $0 \cdot 2-9 \cdot 9 \mathrm{ng} / \mathrm{ml}$. All animals developed oestrus (=day 0 of the oestrous cycle) and were slaughtered in the abattoir of the institute $18-19 \mathrm{~h}$ subsequent to the depherelin treatment. The ovaries 
were removed about $15 \mathrm{~min}$ after the death of the animal and transported within $10 \mathrm{~min}$ to the laboratory. Treatments were approved by the governmental Committee on Animal Use and Care (MecklenburgVorpommern). Because of limited material, a second experiment was designed to complete determinations of the dose-response to $\mathrm{LH}$ and the effect of the phospholipid, platelet activation factor (PAF), on LH responses. Four follicles were used $20 \times 25(n=2)$ and $25 \times 25(n=2) \mathrm{mm}$ in size from four ovaries obtained from cows slaughtered at an abattoir. Presence of regressing corpus luteum in the ipsilateral or contralateral ovary and vascularization were recorded to assess the clinical state of all ovaries.

\section{Preparation of cells, thecal tissue and culture conditions}

Follicles with at least one diameter of at least $15 \mathrm{~mm}$ per pair of ovaries were aspirated, the follicle fluid volume was measured, the granulosa cells spun off $(60 \times \boldsymbol{g}$, $4{ }^{\circ} \mathrm{C}, 10 \mathrm{~min}$ ) after addition of EDTA (to $2 \mathrm{mM}$, $200 \mathrm{mM}$ stock, $\mathrm{pH} \mathrm{7 \cdot 2)}$ to minimize aggregation, and aliquots were stored $\left(-80^{\circ} \mathrm{C}\right)$ for analyses. The cellular sediment was resuspended in double-distilled ice-cold $\mathrm{H}_{2} \mathrm{O}$ for $10 \mathrm{~s}$ to lyse the erythrocytes. Lysis was terminated by the addition of $\mathrm{NaCl}$ (to $150 \mathrm{mM}, 1.5 \mathrm{M}$ stock autoclaved and filtered through a $0 \cdot 2 \mu \mathrm{m}$ filter). An aliquot was used to determine contamination with monocytes and neutrophils by labelling surface antigens as recommended by the manufacturer. Fluorescence of single cells was measured by flow cytometry (Coulter Elite XL) as described previously (Löhrke et al. 1998). The proportion of immunoreactive cells was $<1 \%$ in all granulosal preparations. The remaining cells were collected by centrifugation $\left(60 \times \boldsymbol{g}, 4{ }^{\circ} \mathrm{C}, 10 \mathrm{~min}\right)$ and resuspended in serum-free Ham's F12 medium diluted (1 vol/1 vol) with HBS ( $20 \mathrm{mM}$ Hepes, pH 7·4, $150 \mathrm{mM} \mathrm{NaCl}, 0 \cdot 2 \mathrm{mM}$ EDTA) containing BSA $(0 \cdot 1 \%)$, insulin $(100 \mathrm{ng} / \mathrm{ml})$ and L-glutamine $(3.0 \mathrm{mM})$.

The cells were counted (Coulter counter), cells $>12 \mu \mathrm{m}$ in diameter were recorded, the concentration was adjusted to $0.5 \times 10^{6} / \mathrm{ml}$ and aliquots $(100 \mu \mathrm{l})$ were plated on 96-well culture plates. Viability was tested by trypan blue exclusion. Cells were then treated with additives in a final volume $(110 \pm 1 \mu \mathrm{l})$ to concentrations as indicated. Cell number and integrity were also determined at the end of the culture period $(2 \cdot 5 \mathrm{~h})$. Next, the follicle wall was excised and the thecal layers were dissected under microscopic inspection using sterile surgical tools. Separation of the thecal layers took advantage of the loose theca interna during the vascularized periovulatory stage. After peeling away the theca interna, the theca externa fragments (smooth muscle with attached thecal steroidogenic cells) were prepared without vessels as assessed by microscopy on the analogy of a described technique (Sirois 1994). Three pieces (about $1.0 \times 5.0 \mathrm{~mm}$ in size and $20 \pm 2 \mathrm{mg}$ in wet weight) were plated per well of a 96-well plate using the medium described above. Each treatment for cells and thecal fragments from each follicle was accomplished in triplicate or quadruplicate when not otherwise stated. Incubations were for $2.5 \mathrm{~h}$ at $37^{\circ} \mathrm{C}$. Next, lucigenin was added and chemiluminescence was counted as described below. Then, tissue fragments and aliquots of the supernatant were stored frozen $\left(-80{ }^{\circ} \mathrm{C}\right)$ for further analyses. Lucigenin did not interfere with steroidogenesis and transcript levels as examined by preliminary experiments comparing data with and without lucigenin additions.

\section{Hormone assays}

Progesterone was measured by a direct, singleantibody RIA using purified rabbit antibodies and $\left[1,2,6,7-{ }^{3} \mathrm{H}\right]$ progesterone as tracer. The sensitivity of the assay was $0 \cdot 4 \mathrm{ng} / \mathrm{ml}$. Intra- and interassay coefficients of variation were $10 \%$ and $15 \%$ respectively. The concentration of $17 \beta$-oestradiol in follicle fluids was determined by a ${ }^{3} \mathrm{H}$-RIA after extraction of $17 \beta$-oestradiol by ethylether using purified rabbit antibody (Schneider et al. 2002). The sensitivity was $5 \mathrm{pg} / \mathrm{ml}$, intra- and interassay coefficients of variation were $7 \%$ and $12 \%$ respectively. LH was determined in a parallel study (Schneider et al. 2002) to assess the response of Holstein heifers to the $\mathrm{GnRH}$ analogue used to evoke the LH surge for inducing the development of the large follicles studied here. LH determination was performed by an electrochemiluminescence immunoassay (ECLIA). The assay was based on a sandwich technique using ruthenium (II)-labelled monoclonal antibody and purified rabbit polyclonal antibody against the $\beta$-subunit of LH (Schneider et al. 2002). Chemiluminescence triggered by an electric potential was measured by an ORIGEN 1.5 analyser (IGEN). The sensitivity of the assay was $0.03 \mathrm{ng} \mathrm{LH} / \mathrm{ml}$. The intraand interassay coefficients of variation were $6.4 \%$ and $8.9 \%$ respectively.

\section{RNA extraction}

Thecal tissue was ground into powder under liquid nitrogen using a diethyl pyrocarbonate-treated, autoclaved mortar and pestle. About $10 \mathrm{mg}$ powder were homogenized (Ultra Turrax homogenizer) and total RNA was extracted using an Invitek kit according to the manufacturer's protocol. The concentration of RNA was determined by absorbance at $260 \mathrm{~nm}$. The purity and integrity was assessed by the $260 / 280 \mathrm{~nm}$ ratio and electrophoresis using 2\% agarose in TBE buffer $(89 \mathrm{mM}$ Tris, $89 \mathrm{mM}$ boric acid, $1 \mathrm{mM}$ EDTA, pH 8.0 ) and the SYBR gold stain in a final concentration as recommended by the manufacturer. 


\section{Quantification of transcripts}

Fragments of mRNA encoding COX-2, P450 cholesterol side chain cleavage enzyme (P450 scc), 3 $\beta$-hydroxy-

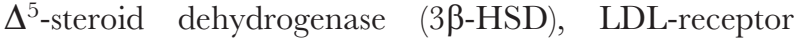
(LDL-R), LRP-receptor (LRP-R), also called $\alpha 2-$ macroglobulin proteinase complex receptor, and lipoprotein lipase (LPL) were obtained from reverse transcription (RT) performed by an iScript cDNA synthesis kit following the protocol of the manufacturer using $100 \mathrm{ng}$ total RNA. The cDNA amount was amplified by real time PCR (iCycler, BIO-RAD) using an iQ-SYBR green supermix. One microlitre of each RT reaction (1/20 of total) was in each $10 \mu \mathrm{l}$ PCR primed with gene-specific oligonucleotides.

The PCR was accomplished by a hot start $(3 \mathrm{~min}$, $94{ }^{\circ} \mathrm{C} ; 30 \mathrm{~s}, 60{ }^{\circ} \mathrm{C} ; 45 \mathrm{~s}, 70{ }^{\circ} \mathrm{C}$ ) followed by 45 cycles $\left(10 \mathrm{~s}, 94^{\circ} \mathrm{C} ; 30 \mathrm{~s}, 60^{\circ} \mathrm{C} ; 45 \mathrm{~s}, 70{ }^{\circ} \mathrm{C}\right.$ with an additional $5 \mathrm{~s}$ each cycle) and terminated by $10 \mathrm{~s}, 94^{\circ} \mathrm{C} ; 30 \mathrm{~s}, 60^{\circ} \mathrm{C}$; $7 \mathrm{~min}, 70^{\circ} \mathrm{C}$ for denaturation, annealing and elongation respectively. The primers were designed to span a corresponding intron and to anneal between $60{ }^{\circ} \mathrm{C}$ and $70{ }^{\circ} \mathrm{C}$ based on the published cDNA and gene sequences. The primer sets (sense/antisense) are shown in Table 1.

The specificity of the products was assessed using a melting point analysis starting at $60{ }^{\circ} \mathrm{C}$ and elevating the temperature to $90^{\circ} \mathrm{C}\left(1^{\circ} \mathrm{C}\right.$ per $\left.10 \mathrm{~s}\right)$. Further assessment was by agarose gel electrophoresis in comparison with oligonucleotide molecular mass ladders to confirm that the calculated molecular mass of the product corresponds to the produced oligonucleotide. The oligonucleotide structure was checked by sequencing in some experiments. The mRNA abundance was calculated using the known concentration of standard oligonucleotides and amplification efficiency displayed by the iCycler.

\section{Detection of lipohydroperoxide (LHP)}

We used an assay kit (Cayman, Grünberg, Germany) following the instructions of the manufacturer with some modifications based on a previous study (Mihaljevic et al. 1996) in order to meet the requirements of limited sample material. Lipids were extracted from LDL or follicle fluid (FF) by vortexing (2 min) equal volumes (routinely $200 \mu \mathrm{l}$ ) of LDL or FF and deoxygenated acidic $\mathrm{CH}_{3} \mathrm{OH}$ that contained the component $\mathrm{R}(5 \mathrm{mg} / \mathrm{ml})$ of the kit using polypropylene tubes. Deoxygenation of $\mathrm{CH}_{3} \mathrm{OH}$ and $\mathrm{CHCl}_{3}$ was performed by the addition of bubbling nitrogen for $50 \mathrm{~min}$ on ice. Next, lipids were transferred into $\mathrm{CHCl}_{3}$ by vortexing with one volume deoxygenated $\mathrm{CHCl}_{3}$ (2 min). After centrifugation $\left(3000 \times \boldsymbol{g}, 5 \mathrm{~min}, 0{ }^{\circ} \mathrm{C}\right)$, the aqueous top layer was removed and the bottom $\mathrm{CHCl}_{3}$ layer collected without the middle solid protein layer by inserting a polypropylene tip down the side of the tube. The lipid extract $\left(\mathrm{CHCl}_{3}\right.$ layer $)$ was stored on ice. Next, standards were prepared from an ethanolic solution of $50 \mu \mathrm{M}$

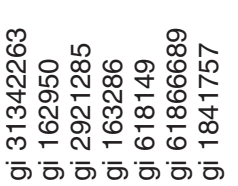

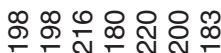

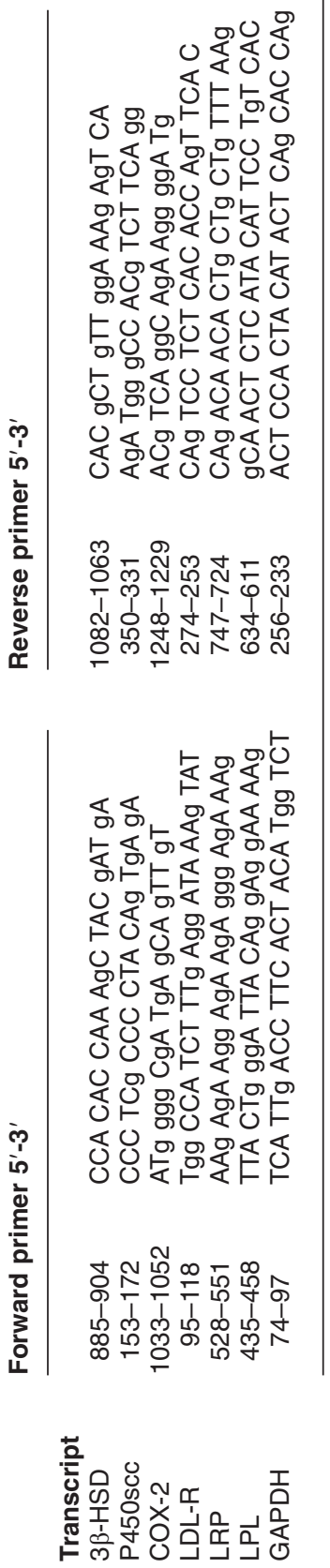


13-hydroperoxyoctadienoic acid (HPODA). A deoxygenated mixture of 2 vol $\mathrm{CHCl}_{3} / 1$ vol $\mathrm{CH}_{3} \mathrm{OH}$ was mixed with HPODA yielding final amounts of 0 (background), 0.2, 0.3, $0 \cdot 4$ and $0 \cdot 6 \mathrm{nmol}$ (total volume of $120 \mu \mathrm{l})$ on ice. Then, to an extract aliquot $(55 \mu \mathrm{l})$ $\mathrm{CHCl}_{3} / \mathrm{CH}_{3} \mathrm{OH}(60 \mu \mathrm{l})$ was added, the chromogen prepared (1 vol $4.5 \mathrm{mM}$ ferrous sulphate in $0.2 \mathrm{M}$ $\mathrm{HCl} / 1$ vol 3\% methanolic ammonium thiocyanate) and added $(5 \mu \mathrm{l})$. Parallel reactions were prepared using triphenylphosphin (to $0.9 \mathrm{mM}$ that abolished colour development using $0 \cdot 6 \mathrm{nmol} \mathrm{HPODA}$ ) to reduce LHP of extracts. The resulting colour was used as background absorbance. The mixtures were immediately transferred into a 96-well glass plate at room temperature and the colour recorded after $20 \mathrm{~min}$ at $490 \mathrm{~nm}$. Absorbances of the background (determinations run in triplicate) were averaged and subtracted from all values. Standard values were plotted vs nmol HPODA. An analysis of linear regression provided the equation (routinely $\left.r^{2}=0 \cdot 99\right)$ used to calculate LHP of samples.

\section{Superoxide anion assay}

Superoxide anions $\left(\mathrm{O}_{2}{ }^{-}\right)$were directly measured by an assay based on the chemilumininescence of lucigenin (bis-N-methylacridinium nitrate) as described previously (Ohara et al. 1993). Briefly, the degree of univalent reduction of oxygen (producing $\mathrm{O}_{2}{ }^{-}$) in our culture conditions was determined spectrophotometrically with xanthine oxidase $(0.004 \mathrm{U})$ and the reduction of ferricytochrome $\mathrm{c}$ in the presence of different xanthine concentrations $(0 \cdot 1-$ $1 \mu \mathrm{M})$. An analysis of linear regression of the transient chemiluminescence signals produced in a manner dependent on the concentration of xanthine resulted in the yield of $\mathrm{O}_{2}{ }^{-}$( $37 \%$ of the xanthine concentration present in the reaction). This value was used to calibrate the lucigenin signal obtained by reactions of xanthine and xanthine oxidase. An analysis of linear regression provided the equation $\left(r^{2}=0.99\right)$ to calculate $\mathrm{O}_{2}{ }^{-}$production from the lucigenin signal elicited by thecal fragments. Lucigenin (6 mM stock in HBS) was added (to $0.20 \mathrm{mM}$ ) into the wells with and without tissue, and transient chemiluminescence signals were immediately measured using a total period of $40 \mathrm{~min}$ and a Fluostar Optima microtitre plate counter (BMG Labtechnologies), a gain of 4095, an emission filter lens for lucigenin and $40 \mathrm{~s}$ records at $37{ }^{\circ} \mathrm{C}$. Reactions without tissue (background control) that were intended to be substracted did not generate signals. This allowed a direct use of the data for calculating $\mathrm{O}_{2} \cdot{ }^{-}$production.

\section{Polar phospholipids from endogenous oxLDL}

Specimens were from Holstein cows on postpartum days 50-55 with high (>40 kg/day) and medium $(<40 \mathrm{~kg} /$ day) lactation associated with different lipohydroperoxide concentrations (Löhrke et al. 2004, 2005b).
Blood was collected via coccygeal arterio-venipuncture, placed on ice and centrifuged after clotting $(3000 \times \boldsymbol{g}$, $\left.15 \mathrm{~min}, \quad 4^{\circ} \mathrm{C}\right)$. Serum was treated with butylated hydroxytoluene (to $20 \mu \mathrm{M}$ ) and 4-(2-aminoethyl) benzenesulphonylfluoride (to $150 \mu \mathrm{M}$ ) to inhibit artificial oxydations and deacylation of phospholipids. Serum $(4 \mathrm{ml})$ was overlaid with $150 \mathrm{mM} \mathrm{NaCl}(2 \mathrm{ml})$ to transfer chylomicrons and very low density lipoproteins into the supernatant by ultracentrifugation $(150000 \times \boldsymbol{g}, 12$ $\left.14 \mathrm{~h}, 10^{\circ} \mathrm{C}\right)$. The supernatant was removed and the infranatant was diluted with 1 vol $150 \mathrm{mM} \mathrm{NaCl}$. LDL was precipitated by addition of an aqueous dextrane sulphate-400 (to $0 \cdot 015 \%$ )- $\mathrm{MgCl}_{2}$ (to $105 \mathrm{mM}$ ) mixture. After $3 \mathrm{~min}$ on ice, LDL was spun off $(5000 \times \boldsymbol{g}, 5 \mathrm{~min}$, $4{ }^{\circ} \mathrm{C}$ ) and dissolved in HBS. LDL particles were protected by sucrose (to $0.43 \mathrm{M}$ ) and stored at $-80{ }^{\circ} \mathrm{C}$. Preparation of LDL from follicular fluid followed this protocol; however, LDL was precipitated by $0.03 \%$ dextrane sulphate-400 $\left(\mathrm{MgCl}_{2}, 210 \mathrm{mM}\right)$. HDL of the supernatant was precipitated through an increase in dextrane sulphate-400 (to 0.045\%). After thawing, lipids were extracted as described under LHP detection, the organic phase evaporated by a stream of nitrogen and the residue resuspended in HBS. Undissolved material was spun off $\left(10000 \times \boldsymbol{g}, 3 \mathrm{~min}, 2{ }^{\circ} \mathrm{C}\right)$. The supernatant was chromatographed (after adjusting the $\mathrm{pH}$ to $5 \cdot 2-5 \cdot 3$ with $1 \mathrm{M} \mathrm{HCl}$ ) using an amberlite XAD-2 column (Salari 1986). The column was prepared as recommended by the manufacturer using $0.5 \mathrm{~g}$ of the dry resin. After loading, the column was washed with $\mathrm{H}_{2} \mathrm{O}(25 \mathrm{ml}$, flow rate of $1 \mathrm{ml} / \mathrm{min})$ and eluted with $\mathrm{CH}_{3} \mathrm{CN}(0.5 \mathrm{ml} / \mathrm{min})$ collecting fractions of $1 \mathrm{ml}$. Polar phospholipids in the first fraction enriched with 1-O-alkyl-2-acyl-sn-glycero-3phosphocholine (Salari 1986) were determined spectrometrically and by phosphorus analysis using a sensitive microassay (Ames \& Dubin 1960). $\mathrm{CH}_{3} \mathrm{CN}$ was evaporated under a stream of nitrogen and the polar phospholipids were dissolved in HBS (to 10 pmol phosphorus/ $\mu$ l). The content of short-chain fatty acid residues bound at the sn-2 position of polar glycerophospholipids was measured after hydrolysis with phospholipase A2 (Tojo et al. 1988) by gas chromatography using isocaproic acid as an internal standard (to $12 \mathrm{mM}$ ) and PAF (1-O-hexadecyl2-acetyl-sn-glycero-3-phosphocholine) as a positive control. Phospholipase A2 released acetic acid from PAF (mol\%, 0.04 \pm 0.008$)$ and short-chain fatty acids from polar phospholipids isolated from oxLDL with 0.5 and $1.5 \mathrm{nmol} / \mathrm{ml}$ lipohydroperoxides as follows ( $\mathrm{mol} \%$ ): acetic acid (0.0042 \pm 0.0005 and 0$)$, n-butyric acid $(0$ and $0 \cdot 003 \pm 0 \cdot 001)$, n-valeric acid $(0$ and $0 \cdot 002 \pm 0 \cdot 001)$, isovaleric acid $(0 \cdot 001 \pm 0.0005$ and $0 \cdot 001 \pm 0 \cdot 0004)$.

\section{Statistical analysis}

Results are presented as means \pm S.E.M. of data from all follicles or from individual follicles (S.E.M. then represents 
Table 2 Characteristics of the individual largest follicles (oestrous cycle day 0) used for further analyses. Data are from $\mathrm{GnRH}$-induced follicles. Mean values are shown of determination per follicle run in duplicate

\begin{tabular}{|c|c|c|c|c|}
\hline & $\begin{array}{l}\text { Follicle fluid } \\
\text { (ml) }\end{array}$ & $\begin{array}{l}\text { P4 } \\
\text { (ng/ml) }\end{array}$ & P4/E2 & $\begin{array}{l}\text { LHP } \\
(\mathrm{nmol} / \mathrm{ml})\end{array}$ \\
\hline \multicolumn{5}{|c|}{ Size (mm) } \\
\hline $25 \times 25$ & $7 \cdot 0$ & 256 & $2 \cdot 6$ & 1.02 \\
\hline $20 \times 20$ & $2 \cdot 0$ & 307 & 11.9 & 0.28 \\
\hline $15 \times 17$ & 1.0 & 82 & 87.9 & 1.22 \\
\hline $15 \times 17$ & 0.8 & 82 & 0.51 & 0.88 \\
\hline $12 \times 15$ & 1.5 & 76 & $21 \cdot 6$ & n.d. \\
\hline
\end{tabular}

P4, progesterone; E2, 17 $\beta$-oestradiol; LHP, total lipohydroperoxides; n.d., not done.

the variability of determinations run at least in triplicate) as indicated.

Pair-wise comparisons and comparisons vs control group (before converting data to relative values) were accomplished by one-way ANOVA and post hoc Newman-Keuls procedure providing ANOVA yielded a significant $\mathrm{F}$ ratio. $P$ values $<0.05$ were considered statistically significant. Tests, logarithmic (lg) transformations of non-linear data sets to linearize the data and analyses of linear regression were performed using SAS statistical package and Sigma Stat of the Jandel Scientific Software. Graphic presentations were accomplished by Sigma Plot of the Jandel Scientific program package (Erkrath, Germany); SAS Institute Inc., Cary, NG, USA.

\section{Results}

\section{Characteristics of the GnRH-induced large follicles}

In response to treatment with $\mathrm{GnRH}$, ovaries developed large follicles differing in size, follicle fluid volume, and lipohydroperoxides in the follicle fluid on oestrous cycle day 0 (Table 2). Data from GnRH-induced large follicles were comparable to those from naturally cyclic ovaries (data not shown). The concentration of lipohydroperoxides (LHP) in total lipids extracted from the follicle fluid varied between 0.28 andl.22 nmol/ml (Table 2). LDL and HDL isolated from the fluid of follicles with a fluid volume $>1 \mathrm{ml}$ contained $0.70 \pm 0.06$ and $0 \cdot 86 \pm 0.02 \mathrm{nmol} / \mathrm{ml} \mathrm{LHP}$. The LHP values of LDL corresponded to the LHP level of circulatory LDL $(0 \cdot 50 \pm 0.022 \mathrm{nmol} / \mathrm{ml})$. The concentration of LHP in circulatory HDL was $1.55 \pm 0.45 \mathrm{nmol} / \mathrm{ml}$. To ascertain the developmental stage of the follicles at the time of their isolation and whether they had responded to the GnRH analogue, follicular fluid concentrations of progesterone and $17 \beta$-oestradiol were determined. Concentrations of progesterone and progesterone/17 $\beta$ oestradiol ratios (Table 2) varied among follicles isolated at an almost identical time $(20 \pm 1$ and $22 \pm 1 \mathrm{~h}$ postGnRH and after the LH surge respectively). The corpus luteum of all ovaries exhibited a strong structural regression indicated by small size, cavitation and absent vascularization. Follicular size or fluid parameters did not correspond with an ipsilateral or contralateral localization of the corpus luteum. No relationship was found between follicle size and follicle fluid characteristics (Table 2).

\section{Effect of PAF and LH on number and progesterone production of granulosa cells}

The number of viable cells after preparation was $98 \pm 2 \%$. A small decrease in the cell number was observed at a low level of PAF $(270 \mathrm{pmol} / \mathrm{ml})$ at the end of the culture period. A decrease occurred at the end of the culture period at levels of PAF higher than $500 \mathrm{pmol} / \mathrm{ml} \quad(540$ and $750 \mathrm{pmol} / \mathrm{ml}, 90 \pm 4$ and $88 \pm 5 \%, P>0.05$ and $P<0.05$ vs control) as opposed to the progesterone production of granulosa cells (data not shown). Cells tended to aggregate into small clumps at the end of a culture period particularly in the presence of $\mathrm{PAF}$, rendering it more difficult to determine cell number. LH used as a positive control $(1 \mathrm{ng} / \mathrm{ml}) \mathrm{did}$ not affect cell number and stimulated progesterone secretion moderately (120 $\pm 10 \%$ vs control) while polar phospholipids (PL) did not significantly influence steroidogenesis of granulosa cells.

\section{Response of thecal progesterone production in vitro to oxLDL and oxLDL-derived PL}

When thecal fragments were exposed to endogenously oxidized LDL containing 0.5 or $1.5 \mathrm{nmol} / \mathrm{ml}$ lipohydroperoxides, the progesterone level of the culture medium decreased significantly (Fig. 1A). A marked increase in response to forskolin which triggers the PKA pathway was observed (Fig. 1A). LDL with $0.5 \mathrm{nmol} / \mathrm{ml}$ LHP tended to inhibit the forskolin effect (Fig. 1A) but the decrease did not reach statistical significance $(P=0 \cdot 052)$. Phospholipids from mildly oxLDL (containing $0.5 \mathrm{nmol} / \mathrm{ml}$ lipohydroperoxides) tended to exert greater effects than those from moderately oxLDL $(1.5 \mathrm{nmol} / \mathrm{ml}$ lipohydroperoxides; Fig. 1A).

Polar phospholipids derived from circulating oxLDL with $0.5 \mathrm{nmol} / \mathrm{ml}$ lipohydroperoxides, corresponding to the LHP concentration of LDL from the follicle fluid, decreased thecal progesterone production $(0 \cdot 51 \pm 0 \cdot 15$ times the control), whereas this response was lost with relatively high concentration (Fig. 1B). A block by WEB 2086 of receptors mediating activity of PL with a structure similar to PAF, tended to mitigate the PL effect on the progesterone level. However, progesterone level differed significantly from the control (Fig. 1B). 


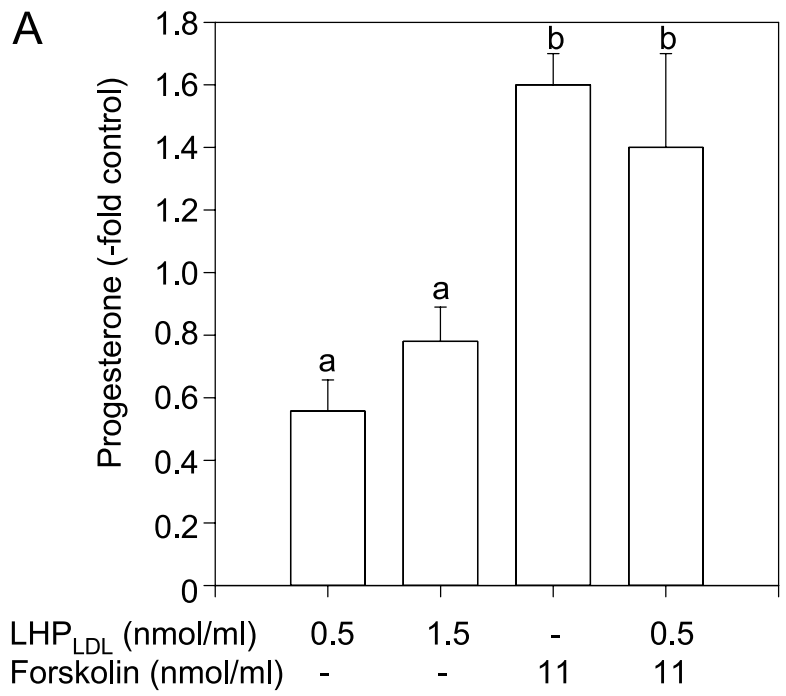

B

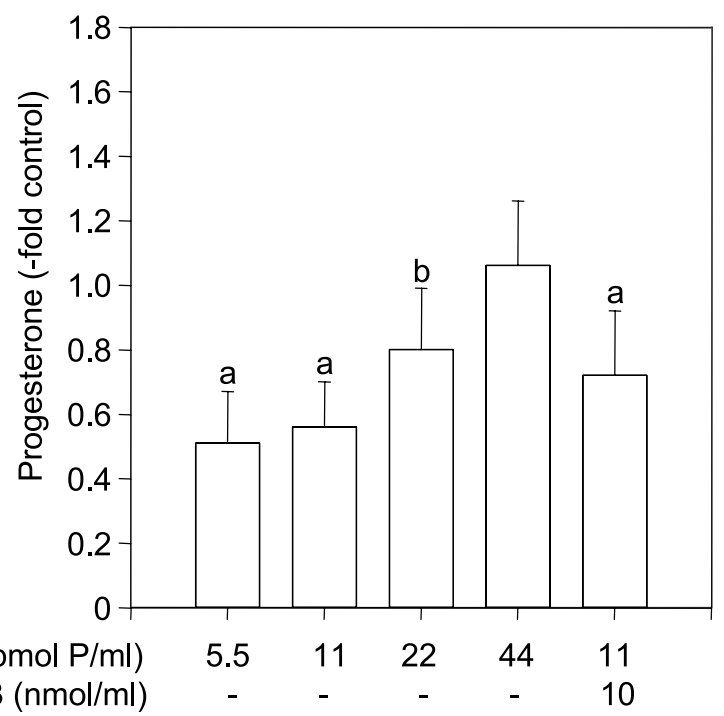

Figure 1 Thecal progesterone production in response to $(A)$ low density lipoprotein (LDL) containing distinct concentrations $(\mathrm{nmol} / \mathrm{ml}$ ) of lipohydroperoxides (LHP, denoted as 0.5 and 1.5 $\mathrm{LHP}_{\mathrm{LDL}}$ ) alone and in the presence of forskolin and (B) polar phospholipids (PL) from LDL with $0.5 \mathrm{nmol} / \mathrm{ml}$ LHP alone or in the presence of the benzodiazepine WEB 2086, a PAF receptor blocker (preincubation, $15 \mathrm{~min}$ ). Basal progesterone production determined at the end of the culture period $(2.5 \mathrm{~h})$ varied among the theca externa of individual follicles (oestrous cycle day 0) between 1.4 and $8.2 \mathrm{ng} / \mathrm{ml} / \mathrm{h}$. Bars denote means \pm S.E.M. ( $\mathrm{GnRH}$-induced follicles from five ovaries), letters denote significant differences $(P<0.05$, ANOVA: $P<0.01$ each) compared with the carrier-treated control. Means without a common letter differ significantly (pair-wise comparisons, $P<0.05)$ from each other and from the control, the mean without a letter is not significantly different from the control. The dose of PL added is denoted by pmol phosphorus $(\mathrm{P}) / \mathrm{ml}$ and that of LHP per LDL preparation by $\mathrm{nmol} / \mathrm{ml}$ as indicated.

\section{Thecal progesterone production in response to PAF}

Hydrolysis of the polar phospholipids with phospholipase A2 indicated the presence of short-chain fatty acid derivatives similar to other studies (Heery et al. 1995, Lehr et al. 1997, Marathe et al. 1999). Such phospholipids may possess PAF-like features. Therefore, thecal fragments were exposed to varying amounts of PAF (Fig. 2A) to test whether oxLDL-derived polar phospholipids mimic PAF effects. These treatments decreased thecal progesterone synthesis (Fig. 2A). The inhibitory impact was lost when WEB 2086 was administered (Fig. 2A). A possible action between PAF and LH was tested at putative physiologic levels (circulatory LH concentrations fluctuated between $0 \cdot 2$ and $9.0 \mathrm{ng} / \mathrm{ml}$ plasma apart from the values of the $\mathrm{LH}$ surge with a peak roughly 10-times the basal level). Interference of PAF with the LH-induced response was detected (Fig. 2B) acting in a dose-dependent manner (Fig. 2B).

\section{Changes in thecal mRNA encoding steroidogenic enzymes and lipoprotein receptors}

The effects of polar phospholipids from endogenously oxidized LDL on thecal progesterone synthesis may involve responses at the level of mRNA encoding steroidogenic enzymes. To test this hypothesis, thecal tissue was incubated with PAF (Fig. 3A,B), oxLDLderived phospholipids and LH (Fig. 3B). The transcripts encoding the P450 scc and $3 \beta$-HSD that direct the P450 scc product, pregnenolone, towards progesterone synthesis were detected in the thecal fragments of all follicles (Fig. 3). The P450 scc mRNA concentration was found

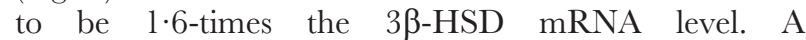
dose-dependent response of thecal mRNA accumulation to PAF was observed with negative maximal effects of $\mathrm{PAF}$ at a level of $270 \mathrm{pmol} / \mathrm{ml}$ (Fig. 3A). A PAF receptor block reversed the negative regulation induced by PAF (Fig. 3A). The thecal response to LH was small (Fig. 3B) while dose-dependent effects of PAF in the presence of LH on mRNA levels were detectable (Fig. 3B). A significant decrease in $\mathrm{P} 450 \mathrm{scc}$ and $3 \beta$-HSD mRNA levels was induced by $270 \mathrm{pmol} / \mathrm{ml} \mathrm{PAF}$ in the presence of LH (Fig. 3B). In contrast, PAF at higher levels induced an increase in thecal 3 $\beta$-HSD and P450 scc mRNA concentrations (Fig. 3B). Forskolin elevated the thecal mRNA accumulation of $3 \beta$-HSD and P450 scc about 6- and 3-times the basal values but PL or PAF did not significantly change the forskolin effect (data not shown). Phospholipids isolated from oxLDL containing $0.5 \mathrm{nmol} / \mathrm{ml}$ lipohydroperoxides decreased mRNA abundance (Fig. 3B). Thecal expression of mRNA encoding some common types of receptors mediating uptake of lipoproteins including oxLDL was tested as a prerequisite for specific lipid effects on intracellular 

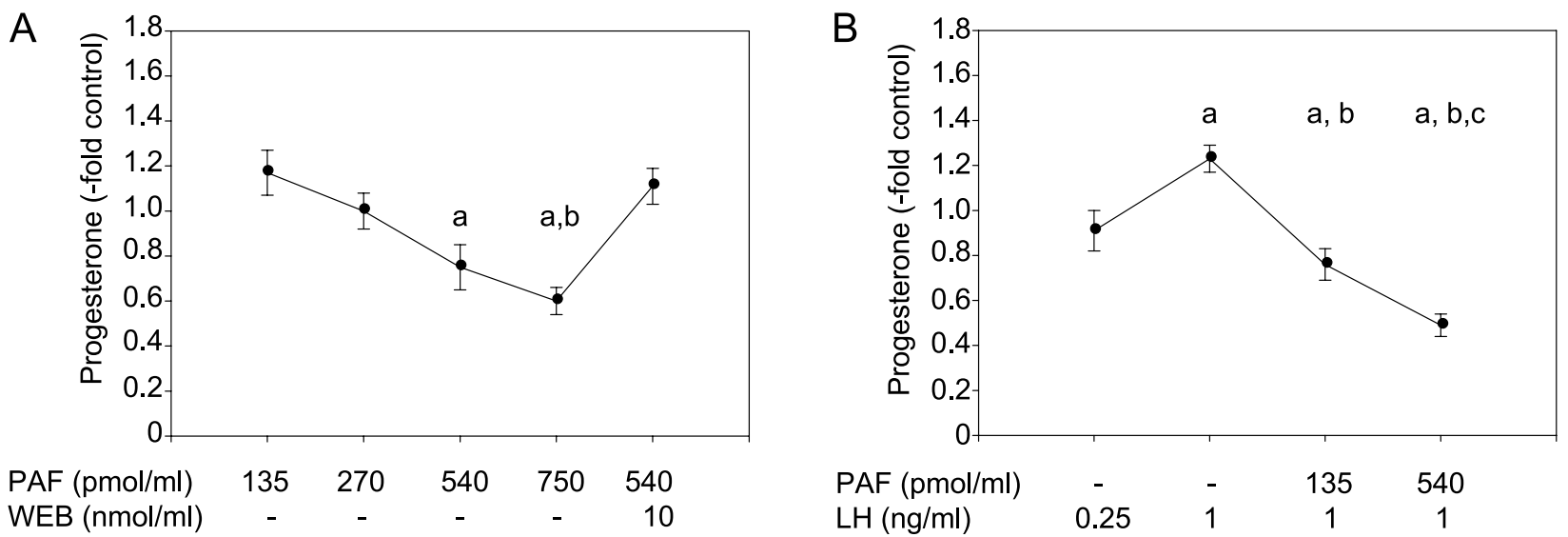

Figure 2 Dose-dependent effect of platelet-activating factor (PAF) on thecal secretion of progesterone relative to the carrier-treated control in (A) the absence and presence of WEB 2086, a PAF receptor blocker and (B) in the presence of LH. Results are means \pm S.E.M. (four follicles from naturally cyclic cows, $>20 \times 20 \mathrm{~mm}$ in size, three to six cultures per treatment, and two determinations of progesterone each). Means with a letter differ significantly from the control, means without a common letter are significantly different in pair-wise comparisons $(P<0.05)$, ANOVA (A) $P<0.02$, (B) $P<0.01$. The progesterone production of the control containing the solvent of PAF (ethanol to $0.001 \%$ ) was $5.0 \pm 0.08 \mathrm{ng} / \mathrm{ml} / \mathrm{h}$.

activities. The levels of these transcripts (Table 3) exceeded about 10-fold the basal level of mRNA encoding steroidogenic enzymes but were 3- to 6-times lower than those of the house-keeping gene, glyceraldehyde-3-phosphate dehydrogenase (GAPDH) (Table 3). Higher concentrations were found in the preovulatory theca interna than in the theca externa (Table 3), in contrast to the GAPDH values (Table 3).

\section{Thecal levels of COX-2 mRNA in response to oxLDL and PAF}

COX-2 transcripts were assayed as an indicator of the preovulatory stage which is associated with elevated production of oxylipids involved in remodelling the follicular wall. The thecal mRNA level of individual follicles varied between 0.01 and $11 \mathrm{pg} / \mu \mathrm{g}$ total RNA (the detection limit of the quantitative RT-PCR was about $5 \mathrm{fg}$ mRNA). These variations were not related to the follicle size or follicle fluid characters shown in Table 2. When thecal tissue was exposed to endogenously oxLDL with $0.5 \mathrm{nmol} / \mathrm{ml}$ lipohydroperoxides $(0.5$ $\mathrm{LHP}_{\mathrm{LDL}}$, Fig. $\left.4 \mathrm{~A}\right)$ or PAF, the COX-2 mRNA decreased significantly (Fig. 4A). The decrease was expressed relative to the control treated with the solvent of the phospholipids because of the strong individual basal fluctuations observed also for P450 scc and $3 \beta$-HSD mRNA (data not shown). Endogenously oxLDL with $1.5 \mathrm{nmol} / \mathrm{ml}$ lipohydroperoxides (1.5 $\mathrm{LHP}_{\mathrm{LDL}}$, Fig. $4 \mathrm{~A}$ ) only tended to exert an effect on relative thecal COX-2 transcript levels (Fig. 4A). To test whether the decrease in thecal COX-2 mRNA levels in vitro has relevance to follicle character in vivo, forskolin-mediated COX-2 mRNA responses (modelling the LH surge in vivo) were plotted compared with the corresponding progesterone $/ 17 \beta$-oestradiol ratios found in the follicular fluid (Fig. 4B). An almost linear function was obtained after log transforming the data, with a significantly negative slope and significant coefficient of determination (Fig. 4B), indicating that COX-2 mRNA levels responded to forskolin after incubation for $2.5 \mathrm{~h}$ in a manner dependent on the ratio between both steroids in the follicle fluid (Fig. 4B). The effect of phospholipids on this response was negligible (data not shown). The function occurred because forskolin increased the COX-2 mRNA levels 212.5-times the basal level at a low progesterone $/ 17 \beta$-oestradiol ratio of the follicle fluid, but the drug almost failed to induce COX-2 transcripts at higher progesterone to $17 \beta$-oestradiol concentrations (Fig. 4B). In contrast to this relationship, basal COX-2 mRNA levels of thecal tissue (cultured without LH or forskolin) correlated with neither thecal steroidogenesis in vitro nor with concentrations of progesterone, $17 \beta$-oestradiol and LHP in the follicle fluid (data not shown).

\section{Relationship between the thecal COX-2 mRNA level and superoxide production}

As PAF and oxLDL (0.5 LHP $\mathrm{LDL}_{\mathrm{LD}}$, Fig. $\left.4 \mathrm{~A}\right)$ induce a significant change in thecal COX-2 mRNA levels, processes related to COX-2 enzyme activity would be expected to change. The activity of the cyclooxygenase enzyme expressed by COX-2 mRNA has an absolute requirement for hydroperoxides such as alkyl peroxides. Such peroxides are precursors for production of reduced oxygen required to form cyclic endoperoxides, converting arachidonic acid into $\mathrm{PGG}_{2} / \mathrm{PGH}_{2}$. Reduced 


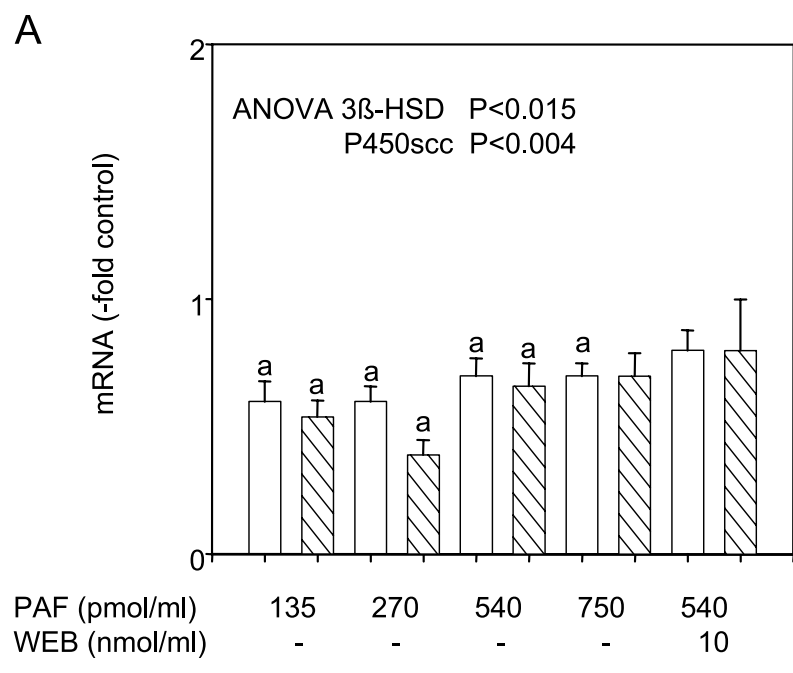

B

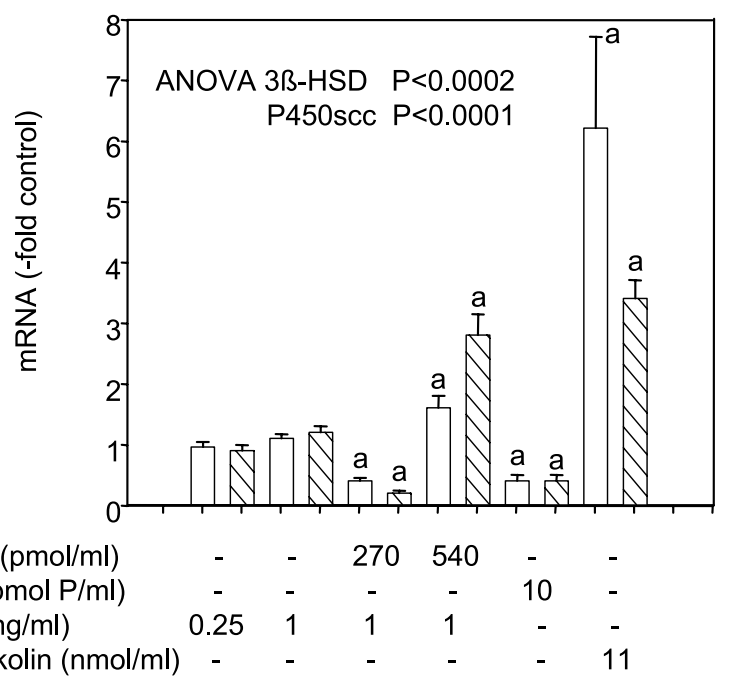

Figure 3 Relative thecal levels of mRNA encoding steroidogenic enzymes in response to (A) PAF using WEB as PAF receptor antagonist and (B) PAF in the presence of $L H$, Forskolin, an activator of PKA signalling and oxLDL-derived PL. Thecal fragments of follicles $>20 \mathrm{~mm}$ in size from four naturally cyclic cows were incubated $(2.5 \mathrm{~h})$ with additives as indicated. Total RNA was extracted and RT-PCR was performed to quantify specific fragments of mRNA encoding $3 \beta$-HSD (open bars) or P450 scc (hatched bars); the respective levels of the controls were $2.9 \pm 0.30$ and $4.0 \pm 0.26 \mathrm{pg}$ $\mathrm{mRNA} / \mu \mathrm{g}$ total RNA $(P<0.05)$. Phospholipids $(\mathrm{PL})$ were isolated from LDL with a lipohydroperoxide concentration of $0.5 \mathrm{nmol} / \mathrm{ml}$ and added according to their content of phosphorus $(P)$. Bars denote means \pm S.E.M., a letter denotes $P<0.05$ (compared with control).

oxygen may also contribute to intrafollicular cell-cell communication during preovulatory remodelling of the follicular wall. We measured thecal generation of
Table 3 Thecal expression of mRNA encoding lipoprotein receptors in comparison with the housekeeping gene, GAPDH. Values are means \pm S.E.M. (four preovulatory follicles)

\begin{tabular}{|c|c|c|}
\hline & 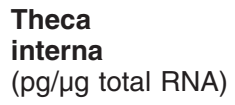 & 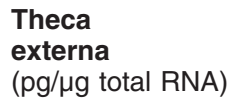 \\
\hline \multicolumn{3}{|l|}{ mRNA type } \\
\hline LDL-R & $52 \pm 19$ & $28 \pm 10$ \\
\hline LRP & $85 \pm 15$ & $27 \pm 4$ \\
\hline LPL & $86 \pm 15$ & $41 \pm 11$ \\
\hline GAPDH & $161 \pm 25$ & $172 \pm 30$ \\
\hline
\end{tabular}

superoxide as an important reduced oxygen species. The thecal production of superoxide anions was found to correlate linearly with the COX-2 mRNA (Fig. 5A) using logarithmically transformed COX-2 mRNA concentrations (Fig. 5A). PAF and 0.5 LHP LDL $_{\text {(Fig. 4A) }}$ inhibited COX-2 mRNA abundance and PAF and oxLDL-derived phospholipid (PL, Fig. 5B) thecal superoxide production, and in this way probably generated the correlation shown (Fig. 5A). WEB 2086 did not completely reverse the effects of PAF (Fig. 5B) but the results no longer differed from the basal value (carrier-treated control, Fig. 5B).

\section{Discussion}

To our knowledge, this is the first study reporting an inhibitory impact of polar phospholipids isolated from mildly and moderately endogenous oxLDL on thecal processes important for ovulation. These processes include progesterone production, superoxide generation, expression of steroidogenic enzymes and of COX-2 transcripts. Inhibition of the corresponding pathways has been reported to block ovulation or to impair fertilization (Tanaka et al. 1991, Behrman et al. 2001, Sirois et al. 2004).

Various pathways regulate progesterone synthesis, including the supply of substrate mediated by several types of lipoprotein receptors and intracellular transporters (Ragoobir et al. 2002, Argov et al. 2004), and cAMP/PKA- and $\mathrm{PGE}_{2}$-signalling (Elvin et al. 2000). We observed a marked preovulatory thecal expression of transcripts encoding lipoprotein receptors. In agreement with previous studies on other ovarian cells or follicle stages (Brannian et al. 1995, Ragoobir et al. 2002, Argov et al. 2004), these observations allow us to conclude that circulating lipoproteins appear to be an important source for preovulatory steroidogenesis. In our study, the cAMP/PKA pathway was experimentally induced by LH or the PKA-activator, forskolin, to obtain a positive control. A significant increase in mRNA encoding $3 \beta-H S D$ and P450 scc together with the progesterone 
A

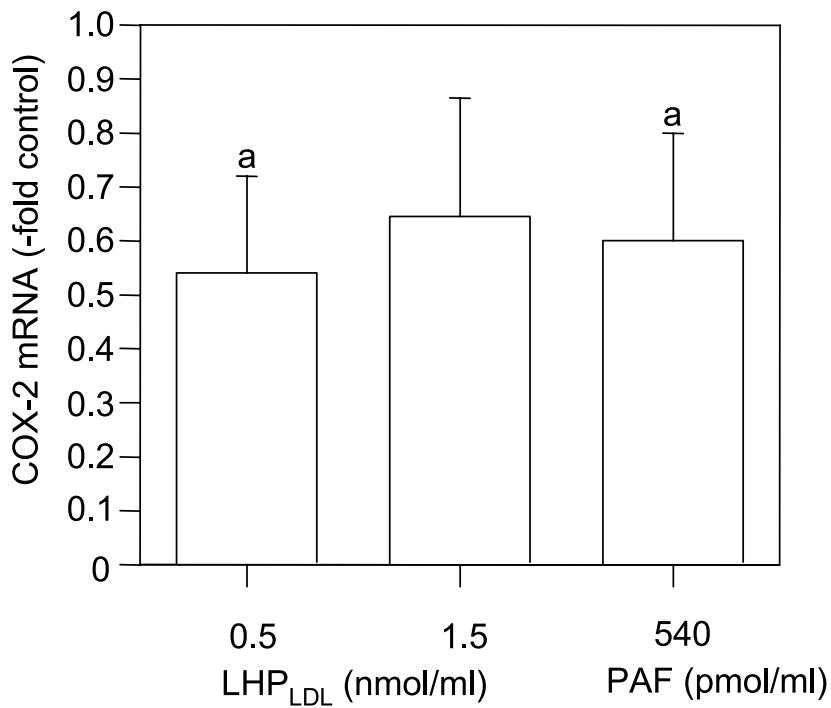

B

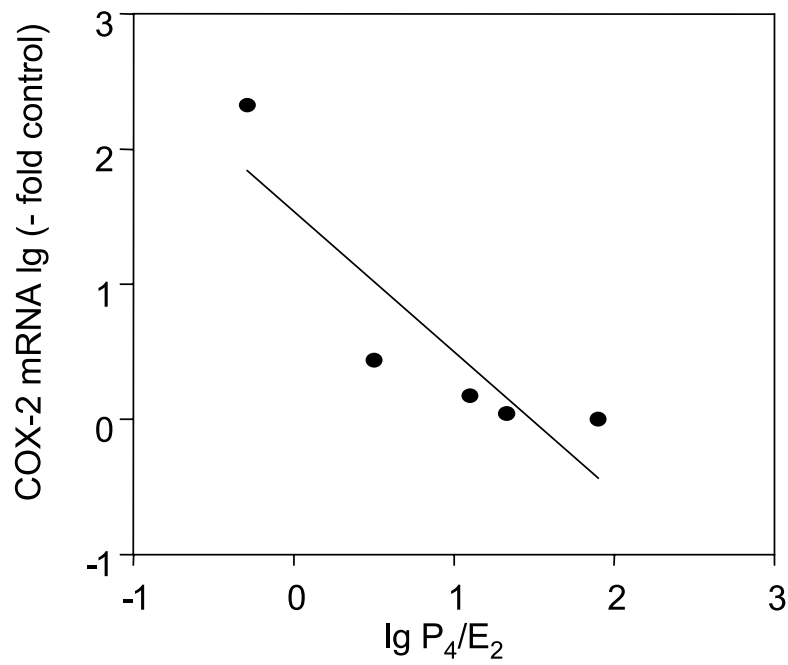

Figure 4 The decrease in thecal cyclooxygenase-2 mRNA levels (A) by PAF and LDL containing lipohydroperoxides (LHP) as indicated and denoted as LHP $\mathrm{LDL}_{2},(B)$ in relation to the progesterone $\left(\mathrm{P}_{4}\right) / 17 \beta$-oestradiol $\left(\mathrm{E}_{2}\right)$ ratio of the follicle fluid (thecal fragments were cultured with $11 \mathrm{nmol} / \mathrm{ml}$ forskolin). COX-2 mRNA was measured by quantitative RT-PCR (iCycler) using specific primers. Transcript abundance was expressed relatively to the carrier-treated control. GnRH-induced follicles from five ovaries were sampled on oestrous cycle day 0 . Progesterone and $17 \beta$-oestradiol were assayed by RIA using follicle fluid corresponding to the follicular theca preparation. Results in $(A)$ are means \pm S.E.M., letters denote values significantly different from the control (ANOVA: $P<0.01$, compared with control, $P<0.05$ ). In $(B)$ transcript levels relative to the control and $P_{4} / E_{2}$ ratios are logarithmically $(\mathrm{lg})$ transformed to linearize the relationship, COX-2 mRNA (-fold control) $=1.54( \pm 0.37)-1.04( \pm 0.31) \mathrm{lg} \mathrm{P}_{4} / \mathrm{E}_{2}$, $P=0.044$ for the slope of the linear regression function, $r^{2}=0.79$.

level was already evident after $2 \cdot 5 \mathrm{~h}$ incubation with forskolin, indicating cAMP signalling was primed in vivo by the LH surge. Phospholipids failed to impair the forskolin-triggered increase in progesterone synthesis as opposed to LH-stimulated progesterone production, suggesting that postreceptor cAMP signalling is little affected by these lipids. Long-term regulation of mammalian steroid hormone synthesis occurs principally by transcriptional regulation of the gene for the rate-limiting cholesterol side-chain cleavage enzyme P450 scc (Moore et al. 1990). Its expression is positively regulated via the cAMP-PKA pathway; negative regulation includes elevation of the intracellular free $\mathrm{Ca}^{2+}$ level (Moore et al. 1990). Our culture conditions avoided increases in $\mathrm{Ca}^{2+}$ levels by the presence of a low final concentration of EDTA $(0.1 \mathrm{mM})$, thereby allowing, perhaps, thecal cells to maintain higher concentration of $\mathrm{P} 450 \mathrm{scc}$ mRNA relative to the 3ß-HSD mRNA level.

Ovarian regulation of bovine $3 \beta$-HSD expression is not clear (Bao et al. 1997). Differentiation of bovine dominant follicles into the preovulatory stage has been reported to be accompanied by an increase in thecal 3ß-HSD mRNA (Tian et al. 1995) but also by a decrease immediately after the LH surge (Voss \& Fortune 1993). Progesterone has been reported to decrease and LH, follicle-stimulating hormone and 17ß-oestradiol to increase human 3ß-HSD activity (Sasano et al. 1990). We found that a significant decrease in progesterone in response to PAF corresponded to a significant decline in thecal 3ß-HSD and P450 scc mRNA. However, negative effects were highest when the preovulatory theca fragments were exposed to $270 \mathrm{pmol} / \mathrm{ml} \mathrm{PAF}$. Higher PAF concentrations $(>540 \mathrm{nmol} / \mathrm{ml})$ did not significantly decrease P450 scc mRNA. A PAF receptor block fully abolished the negative impact, indicative of specific responses. Dose-dependent effects were also detected when the preovulatory theca was exposed to $\mathrm{PAF}$ in the presence of $\mathrm{LH}$, indicating that PAF interferes with thecal LH signalling depending on the concentration of PAF. A comparison with progesterone responses reveals that these responses of mRNA encoding steroidogenic enzymes do not always resemble those of progesterone. The dose-dependent responses of mRNA-encoding steroidogenic enzymes to PAF or oxLDL-derived PL in the absence and presence of LH may be explained by the effects of these phospholipids on a pathway additional to cAMP/PKA signalling. Recently, COX-2 mRNA expression has been reported to be regulated by a switch from cAMP/PKA to PKC dependence during luteinization of preovulatory bovine granulosa cells cultured with forskolin (Wu \& Wiltbank 

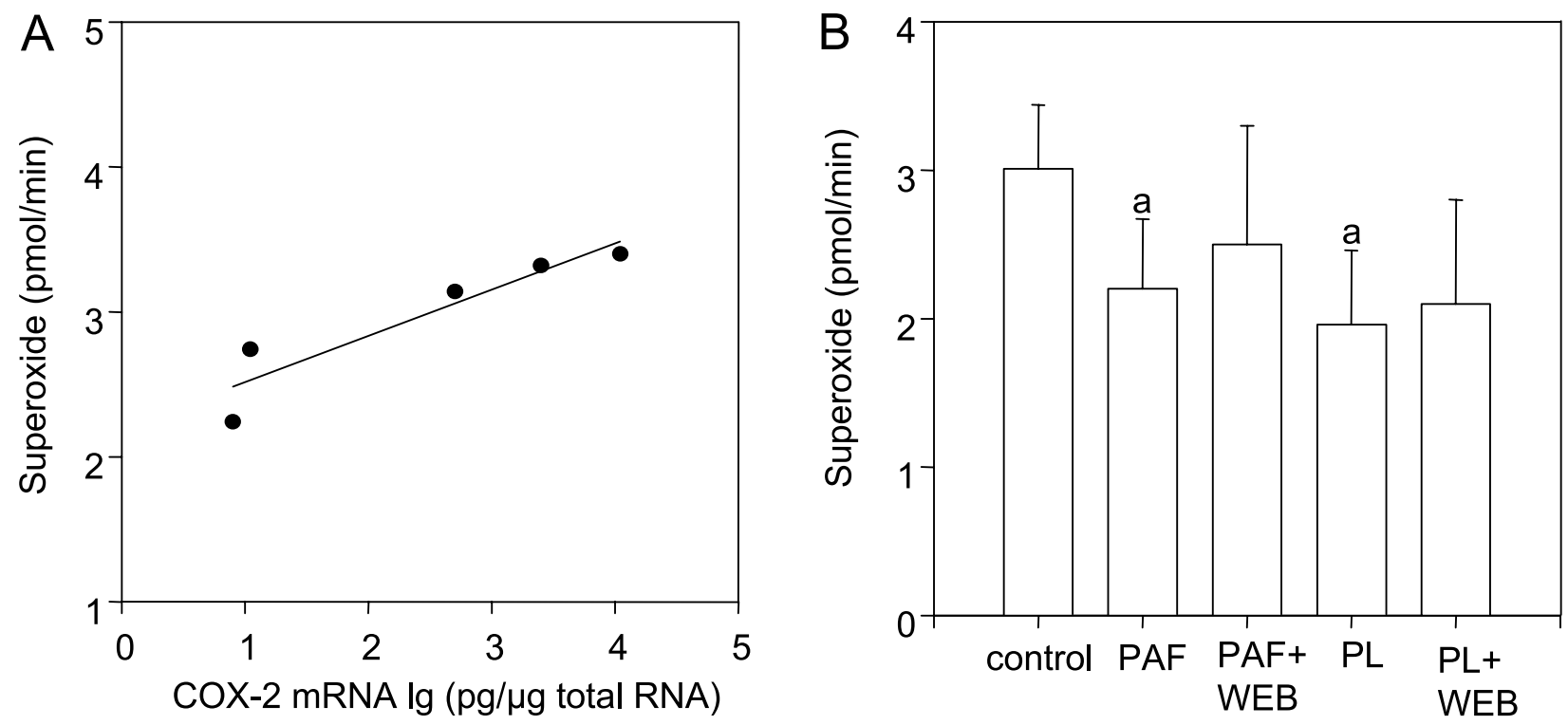

Figure 5 Thecal superoxide production is related to thecal cyclooxygenase (COX-2) mRNA level and responds to oxLDL-derived polar phospholipids (PL). Thecal fragments from $\mathrm{GnRH}$-induced follicles (five ovaries, oestrous cycle day 0 ) were incubated with lucigenin $(0.2 \mathrm{mM})$, a specific superoxide anion detector. Total RNA was extracted and the COX-2 mRNA quantified by RT-PCR (iCycler). (A) Each symbol denotes an individual follicle, assays run in duplicate. An analysis of linear regression resulted in the equation, $\mathrm{pmol} / \mathrm{min}=2.20( \pm 0.19)+0.32( \pm 0.07) \mathrm{lg}\left(\mathrm{pg}\right.$ COX-2 mRNA $/ \mu \mathrm{g}$ total RNA) with $P=0.021$ for the slope and $r^{2}=0.87$. (B) Results are means \pm S.E.M., the letter denotes a significant difference compared with the carrier-treated control (ANOVA: $P<0.01$, compared with control: $P<0.05)$. PAF $(540 \mathrm{pmol} / \mathrm{ml})$, platelet-activating factor; $\mathrm{PL}(11 \mathrm{pmol}$ phosphorus $/ \mathrm{ml})$, polar phospholipids from LDL with $0.5 \mathrm{nmol} / \mathrm{ml}$ lipohydroperoxides; WEB, WEB $2086(10 \mathrm{nmol} / \mathrm{ml})$, a specific PAF receptor blocker.

2002). Further experiments are required to elucidate whether thecal transcripts encoding COX-2 and steroidogenic enzymes are regulated in this manner.

Basal thecal progesterone synthesis differed among individual follicles. For that reason the effect of phospholipids on progesterone production of cultured thecal tissue was expressed relative to the basal rate. A significant inhibitory impact was found for polar phospholipids isolated from oxLDL containing $0.5 \mathrm{nmol} / \mathrm{ml}$ and $1.5 \mathrm{nmol} / \mathrm{ml}$ lipohydroperoxides, but the latter tended to exert a weaker effect. Cell lysis cannot be fully excluded as a source of progesterone released into the culture medium. Such an effect may contribute to a loss of significant difference compared with basal progesterone levels with increasing PL concentration. In turn, phospholipids have also been reported to assist the complex intracellular mechanism splitting off the side chain of cholesterol by P450 scc (Solano et al. 1984), providing, in this manner, more precursors for progesterone synthesis (but also byproducts, such as 4-methyl-pental and $\mathrm{NADP}^{+}$through oxidation of NADPH, consequently inducing possible changes in the intracellular redox state and in the activity of redox-sensitive transcription factors such as nuclear factor kappa B (NFкB)). Stronger responses to mildly compared with moderately oxidized LDL have recently been reported using cell death analysis of macrophages and of smooth muscle cells. The differences were explained by divergent content of degradation products of oxidized lipids (Carpenter 2003). The amberlite XAD-2 column used to isolate polar phospholipids does not retain such products after thorough washing. However, the first fraction of the eluation with acetonitril contains polar phospholipids, mainly acyl and alkyl phosphatidylcholines (Salari 1986) generated by oxidation of phosphatidylcholines that induces a plethora of chemically related phosphatidylcholines (Marathe et al. 1999). In agreement with previous reports (Lehr et al. 1997, Marathe et al. 1999), this was indicated by the release of short-chain fatty acids by phospholipase A2 hydrolysis of polar phospholipids isolated from endogenously oxidized LDL.

In contrast to phosphatidylethanolamines, fragmented alkyl phosphatidylcholines have PAF-like bioactivities (Heery et al. 1995, Marathe et al. 1999). Therefore, PAF was tested to see whether it exerts effects similar to isolated polar phospholipids. Our results indicate that the thecal responses to polar phospholipids from oxLDL with $0.5 \mathrm{nmol} / \mathrm{ml}$ lipohydroperoxides were mimicked by PAF, suggesting PAF-like phospholipids may be responsible for the inhibitory effects. Additionally, these data suggest that dilution of isolated polar phospholipids with related, but less active, diacyl homologues is unlikely to induce the effects observed. Inhibitory 
activity may occur at the intracellular level, since synthetic oxylipids have been reported to interrupt transmitochondrial cholesterol transport (Kodaman et al. 1994). In addition, a block of PAF receptors by an antagonist, WEB 2086 (Lehr et al. 1997), did not always fully reverse the inhibitory actions.

A preovulatory LH surge not only increases progesterone production that triggers expression of thecal proteolytic enzymes (Robker et al. 2000) capable of degrading the perifollicular matrix but also induces the production of local mediators stimulating follicular blood flow, vascular permeability and follicular volume (Tsafriri \& Reich 1999). These mediators include eicosanoids and oxygen radicals that are also required for the resumption of meiosis (Behrman et al. 2001). Both lipoxygenase and cyclooxygenase pathways seem to play a role in the ovulatory process and are expressed in response to the preovulatory LH surge (Mikuni et al. 1998). Little information exists about bovine thecal expression of COX-2 mRNA; therefore we focused on COX-2 mRNA expression reported to be a marker of the preovulatory follicle (Sirois et al. 2004). Owing to suicidal COX-2 inactivation (Kulmacz et al. 1994), mRNA levels are closely related to COX-2 enzyme activity. This activity requires hydroperoxides and generates oxygen radicals (Smith et al. 1996) that are necessary for the conversion of arachidonic acid and $\mathrm{O}_{2}$ to $\mathrm{PGH}_{2}$, the committed step in prostanoid biosynthesis. We observed an interference of PAF and oxLDL with thecal COX-2 mRNA levels, superoxide generation and LH-induced progesterone production. Some evidence for the relevance of this in vivo was obtained by the significant relationship between these findings in vitro and the data from analysis of the follicle fluid representing the follicle state in vivo.

Such a significant correlation between the progesterone/17 $\beta$-oestradiol ratio of the follicle fluid and the relative thecal COX-2 mRNA levels was detected only after a thecal response to forskolin that might model a preovulatory LH surge. The drug strongly stimulated the COX-2 abundance up to $>200$ times the basal value in a low progesterone/17 $\beta$ oestradiol ratio of the follicle fluid, indicating an early, transient period of the preovulatory stage. The result is consistent with bovine data indicating acute regulation of COX-2 mRNA by cAMP signalling about $18 \mathrm{~h}$ after the LH surge (Sirois 1994). The thecal basal COX-2 mRNA levels varied between individual follicles but corresponded to reported bovine values (Tsai et al. 1996). Notably, basal concentrations were related neither to the follicle size nor to the progesterone/17 $\beta$-oestradiol ratio of the follicle fluid. These observations suggest individual differences in follicle development because COX-2 mRNA elevation occurs only during a narrow periovulatory window (Ando et al. 1998, Wu \& Wiltbank 2002, Sirois et al. 2004). Thus, the analysis of follicles with a divergent developmental stage allowed us to elicit a forskolin-induced correlation between COX-2 mRNA expression and the progesterone/17 $\beta$-oestradiol ratio of the follicle fluid, i.e. the microenvironment within the follicle in vivo, a result consistent with previous data (Sirois 1994, Tsai et al. 1996).

Isolated phospholipids and PAF decreased basal thecal COX-2 abundance whereas forskolin-evoked responses were not changed, suggesting that phospholipids did not exert significant effects on forskolin-induced signalling towards COX-2 mRNA transcription. These data resemble those of the progesterone response. Since prostanoid metabolism has been reported as a source of superoxide anions in other tissues (Kontos et al. 1985, Ohara et al. 1993), the basal COX-2 mRNA level was plotted against thecal superoxide production. This plot resulted in a significant slope, however, with an apparent intercept (because of log transformation of the data) of roughly 2 pmol $\mathrm{O}_{2}{ }^{-} / \mathrm{min}$. This indicates that the portion of COX-2 activity that may account for about $30 \%$ of the total thecal superoxide production arises from numerous sources such as the mitochondrial electron transport chain (Loschen et al. 1974) and cytochrome P450 enzymes (Sligar et al. 1974). The relationship may be part of the interaction, since superoxide stimulates the transcription factor $\mathrm{NF \kappa B}$ involved in the stimulation of the COX-2 mRNA transcription (Allen \& Tresini 2000). Polar phospholipids decreased thecal superoxide production to a level corresponding to the apparent intercept of the linearized regression between basal COX-2 mRNA concentration and thecal superoxide production. The result suggests that phospholipids may inhibit COX-2 sources of superoxide. However, more specific experiments are required to clarify the mechanism, since forskolininduced COX-2 mRNA expression did not parallel superoxide production linearly.

The follicle fluid of all large oestrous cycle day 0 follicles contained between 0.28 and $1.22 \mathrm{nmol} / \mathrm{ml}$ lipohydroperoxides. The LDL-associated LHP concentration was found to correspond to these values, suggesting that the concentration used to elicit these effects was physiologic. Apparently, no information about lipohydroperoxide concentration in bovine follicle fluid is available. Previous investigations have reported that phospholipids and their oxidized forms are present in the human follicle fluid and may arise from diffusion/transudation via the follicular wall vascularized and permeabilized during preovulatory maturation (Lopez Bernal et al. 1992, Narahara et al. 1996).

In the porcine fluid, cytochrome P450 (lipoxygenase and cyclooxygenase)-derived metabolites of polyunsaturated fatty acids, including arachidonate and linoleate epoxides, were detected by liquid chromatography (HPLC) tandem mass spectrometry (Newman et al. 2004). The concentrations were up to $0 \cdot 15 \mathrm{nmol} / \mathrm{ml}$ 
with a higher epoxide/diol ratio $(0 \cdot 45)$ in samples from the pre-oestrous group compared with other stages $(0 \cdot 06-0 \cdot 07)$. The colourimetric method used in the present study has been reported to assay lipohydroperoxides (Mihaljevic et al. 1996). Non-hydroperoxidegenerated colour was determined by addition of triphenylphosphine into parallel reactions to reduce hydroperoxides. Specific colour was about $25 \%$ of the total colour. In turn, the HPLC tandem mass spectrometry recoveries of epoxyeicosanoids, which may give rise to very reactive lipid alkoxyl radicals and may produce colour in the assay used here, was also only approximately 25\% (Newman et al. 2002). Therefore, alternative techniques to measure peroxidized lipids more exactly seem to be lacking. Consistent with the porcine data (Newman et al. 2004), the concentration of oxylipids in the bovine follicle fluid did not correlate with other follicle parameters. However, uptake of or exposition to circulatory reactive phospholipids, such as PAF and PAF-like phospholipids, may be a source of interference with oxylipids produced by thecal cyclooxygenase and lipoxygenase pathways (Spector et al. 2004) essential for ovulatory regulation (Mikuni et al. 1998, Acosta et al. 2003).

In summary, the present study indicates an impairment of thecal progesterone production, COX-2 mRNA concentration and superoxide anion generation by polar phospholipids isolated from circulatory, endogenous oxLDL. These responses were mimicked by PAF but were not found to be unequivocally mediated via the PAF receptor; therefore, the role of this receptor should be fully explored in future studies. Unfavourable effects of lipids have been implicated in reproductive abnormalities, such as amenorrhaea and anovulation frequently observed in disorders of energy metabolism $\mathrm{Mu}$ et al. 2001). These effects on female reproduction seem to occur in single-ovulating species at a preovulatory stage, since the development of dominant follicles was not a limiting factor in the bovine reproductive recovery postpartum at different energy balance and dietary fat levels (Beam \& Butler 1997). Such responses mimic COX-2 gene knock-out and COX-2 inhibition in vivo and in vitro (Lim et al. 1997, Mikuni et al. 1998, Davis et al. 1999). Thus, the present observations may contribute to a better understanding of the effects of lipid on female reproductive dysfunction.

\section{Acknowledgements}

The authors declare that there is no conflict of interest that would prejudice the impartiality of this scientific work. We owe gratitude to Prof. W. Kanitz for promoting and supporting our work. Appreciation is expressed to Mrs A. Antkewitz, Mrs C. Pōppel, Mrs S. Radewald and Mrs R. Hantel for excellent assistance.

\section{References}

Acosta TJ, Hayashi KG, Ohtani M \& Miyamoto A 2003 Local changes in blood flow within the preovulatory follicle wall and early corpus luteum in cows. Reproduction 125 759-767.

Acton S, Rigotti A, Landschutz KT, Xu S, Hobbs HH \& Krieger M 1996 Identification of scavenger receptor SR-BI as a high density lipoprotein receptor. Science 271 518-520.

Allen RG \& Tresini M 2000 Oxidative stress and gene regulation. Free Radical Biology and Medicine 28 463-499.

Ames BN \& Dubin DT 1960 The role of polyamines in the neutralization of bacteriophage deoxyribonucleic acid. Fournal of Biological Chemistry 235 769-775.

Ando M, Kol S, Kokia E, Ruutiainen-Altman K, Sirois J, Rohan RM, Payne DW \& Adashi EY 1998 Rat ovarian prostaglandin endoperoxide synthase-1 and -2: periovulatory expression of granulosa cell-based interleukin-1-dependent enzymes. Endocrinology 139 2501-2508.

Argov N, Moallem U \& Sklan D 2004 Lipid transport in the developing bovine follicle: messenger RNA expression increases for selective uptake receptors and decreases for endocytosis receptors. Biology of Reproduction 71 479-485.

Azhar S, Tsai L, Medicherla S, Chandraekher Y, Giudice L \& Reaven E 1998 Human granulosa cells use high density lipoprotein cholesterol for steroidogenesis. Fournal of Clinical Endocrinology and Metabolism 83 983-991.

Bao B, Thomas MG, Griffith MK, Burghardt RC \& Williams GL 1995 Steroidogenic activity, insulin-like growth factor-I production, and proliferation of granulosa and theca cells obtained from dominant preovulatory and nonovulatory follicles during the bovine estrous cycle: effects of low-density and high-density lipoproteins. Biology of Reproduction 53 1271-1279.

Bao B, Garverick HA, Smith GW, Smith MF, Salfen BE \& Youngquist RS 1997 Expression of messenger ribonucleic acid (mRNA) encoding 3 beta-hydroxysteroid dehydrogenase delta4, delta5 isomerase (3 beta-HSD) during recruitment and selection of bovine ovarian follicles: identification of dominant follicles by expression of 3 beta-HSD mRNA within the granulosa cell layer. Biology of Reproduction 56 1466-1473.

Beam SW \& Butler WR 1997 Energy balance and ovarian follicle development prior to the first ovulation postpartum in dairy cows receiving three levels of dietary fat. Biology of Reproduction $\mathbf{5 6}$ 133-142.

Behrman HR, Kodaman PH, Preston SL \& Gao S 2001 Oxidative stress and the ovary. Fournal of the Society of Gynecological Investigation $840-42$.

Brannian JD, Larson EA, Kurz SG \& Chaput GM 1995 Hydrogen peroxide suppresses low-density lipoprotein (LDL) uptake and LDL-supported steroidogenesis by porcine luteal cells. Molecular and Celluar Endocrinology $111213-218$.

Carpenter KL, Challis IR \& Arends MJ 2003 Mildly oxidized LDL induces more macrophage death than moderately oxidized LDL: roles of peroxidation, lipoprotein-associated phospholipase A2 and PPARgamma. FEBS Letters 553 145-150.

Carroll DJ, Grummer RR \& Mao FC 1992 Progesterone production by cultured luteal cells in the presence of bovine low- and high-density lipoproteins purified by heparin affinity chromatography. Fournal of Animal Sciences 70 2516-2526.

Chu L \& Pizzo SV 1994 Alpha 2-macroglobulin, complement, and biologic defense: antigens, growth factors, microbial proteases, and receptor ligation. Laboratory Investigation 71 792-812.

Davis BJ, Lennard DE, Lee CA, Tiano HF, Morham SG, Wetsel WC \& Langenbach R 1999 Anovulation in cyclooxygenase-2-deficient mice is restored by prostaglandin $\mathrm{E}_{2}$ and interleukin-1 beta. Endocrinology 140 2685-2695.

Elvin JA, Yan C \& Matzuk MM 2000 Growth differentiation factor-9 stimulates progesterone synthesis in granulosa cells via a prostaglandin $\mathrm{E}_{2} / \mathrm{EP}_{2}$ receptor pathway. PNAS 97 10288-10293. 
Glister C, Richards SL \& Knight PG 2005 Bone morphogenetic proteins (BMP) $-4,-6$, and -7 potently suppress basal and luteinizing hormone-induced androgen production by bovine theca interna cells in primary culture: could ovarian hyperandrogenic dysfunction be caused by a defect in thecal BMP signaling? Endocrinology 146 1883-1892.

Golos TG, August AM \& Sttrauss JF 3rd 1986 Expression of low density lipoprotein receptor in cultured human granulosa cells: regulation by human chorionic gonadotropin, cyclic AMP, and sterol. Fournal of Lipid Research 27 1089-1096.

Heery JM, Kozak M, Stafforini DM, Jones DA, Zimmerman GA, McIntyre TM \& Prescott SM 1995 Oxidatively modified LDL contains phospholipids with platelet-activating factor-like activity and stimulates the growth of smooth muscle cells. Fournal of Clinical Investigation 96 2322-2330.

Ireland JLH, Jimenz-Krassel F, Winn ME, Burns DS \& Ireland JJ 2004 Evidence for autocrine or paracrine roles of $\alpha_{2}$-macroglobulin in regulation of estradiol production by granulosa cells and development of dominant follicles. Endocrinology $1452784-2794$.

Jaspard B, Fournier N, Vieitz G, Atger V, Barbaras R, Vieu C, Manent J, Chap H, Perre B \& Collet X 1997 Structural and functional comparison of HDL from homologous human plasma and follicular fluid. A model for extravascular fluid. Arteriosclerosis, Thrombosis and Vascular Biology 17 1605-1613.

Jo M, Komar CM \& Fortune JE 2002 Gonadotropin surge induces two separate increases in messenger RNA for progesterone receptor in bovine preovulatory follicles. Biology of Reproduction $\mathbf{6 7}$ 1981-1988.

Kodaman PH, Aten RF \& Behrman HR 1994 Lipid hydroperoxides evoke antigonadotropic and antisteroidogenic activity in rat luteal cells. Endocrinology 135 2723-2730.

Kontos HA, Wei EP, Ellis EF, Jenkins LW, Povlishock JT, Rowe GT \& Hess ML 1985 Appearance of superoxide anion radical in cerebral extracellular space during increased prostaglandin synthesis in cats. Circulation Research 57 142-151.

Kulmacz RJ, Pendleton RB \& Lands WE 1994 Interaction between peroxidase and cyclooxygenase activities in prostaglandin-endoperoxide synthase. Interpretation of reaction kinetics. Fournal of Biological Chemistry 269 5527-5536.

Lehr HA, Weyrich AS, Saetzler RK, Jurek A, Arfors KE, Zimmerman GA, Prescott SM \& McIntyre TM 1997 Vitamin C blocks inflammatory platelet-activating factor mimetics created by cigarette smoking. Fournal of Clinical Investigation 99 2358-2364.

Lim H, Paria BC, Das SK, Dinchuk JE, Langenbach R, Trzaskos JM \& Dey SK 1997 Multiple female reproductive failures in cyclooxygenase 2-deficient mice. Cell 91 197-208.

Löhrke B, Viergutz T, Shahi SK, Pohland R, Wollenhaupt K, Goldammer T, Walzel H \& Kanitz W 1998 Detection and functional characterisation of the transcription factor peroxisome proliferator-activated receptor gamma in lutein cells. Fournal of Endocrinology 159 429-439.

Löhrke B, Viergutz T, Kanitz W, Göllnitz K, Becker F, Hurtienne A \& Schweigert FJ 2004 High milk yield in dairy cows associated with oxidant stress. Online Fournal of Veterinary Research 8 70-78.

Löhrke B, Viergutz T, Kanitz W, Losand B, Weiss DG \& Simko M $2005 a$ Hydroperoxides in circulating lipids from dairy cows: implications for bioactivity of endogenous-oxidized lipids. Fournal of Dairy Science 88 1708-1710.

Löhrke B, Viergutz T, Kanitz W, Becker F, Göllnitz K, Hurtienne A \& Schweigert FJ $2005 b$ Der Zusammenhang zwischen Milchleistung und oxidativem Stress bei Milchkühen. Berliner Münchener Tierä rtzliche Wochenschrift 118 265-269.

Lopez Bernal A, Newman GE, Phizackerley PJ, Laird E, Ross C \& Barlow DH 1992 Platelet-activating factor levels in human follicular and amniotic fluids. European Fournal of Obstetrics, Gynecology and Reproductive Biology 46 39-44.
Loschen G, Azzi A, Richter C \& Flohe L 1974 Superoxide radicals as precursors of mitochondrial hydrogen peroxide. FEBS Letters 42 68-72.

Lydon JP, DeMayo FJ, Conneely OM \& O’Malley BW 1996 Reproductive phenotypes of the progesterone receptor null mutant mouse. Fournal of Steroid Biochemistry and Molecular Biology 56 $67-77$.

Mamluk R, Wolfenson D \& Meidan R 1998 LH receptor mRNA and cytochrome $\mathrm{P} 450$ side-chain cleavage expression in bovine theca and granulosa cells luteinized by LH or forskolin. Domestic Animal Endocrinology 15 103-114.

Marathe GK, Davis SS, Harrison KA, Silva AR, Murphy RC, Castro-Faria-Neto H, Prescott SM, Zimmerman GA \& McIntyre TM 1999 Inflammatory platelet-activating factor-like phospholipids in oxidized low density lipoproteins are fragmented alkyl phosphatidylcholines. Fournal of Biological Chemistry 274 28395-28404.

Mihaljevic B, Katusin-Razem B \& Razem D 1996 The reevaluation of the ferric thiocyanate assay for lipid hydroperoxides with special considerations of the mechanistic aspects of the response. Free Radical Biology and Medicine 21 53-63.

Mikuni M, Yoshida M, Hellberg P, Peterson CA, Edwin SS, Brannstrom M \& Peterson CM 1998 The lipoxygenase inhibitor, nordihydroguaiaretic acid, inhibits ovulation and reduces leukotriene and prostaglandin levels in the rat ovary. Biology of Reproduction $\mathbf{5 8}$ 1211-1216.

Moore CC, Brentano ST \& Miller WL 1990 Human P450 scc gene transcription is induced by cyclic AMP and repressed by 12-O-tetradecanoylphorbol-13-acetate and A23187 through independent cis elements. Molecular Cell Biology 10 6013-6023.

Mu YM, Yanase T, Nishi Y, Tanaka A, Saito M, Jin CH, Mukasa C, Okabe T, Nomura M, Goto K \& Nawata H 2001 Saturated FFAs, palmitic acid and stearic acid, induce apoptosis in human granulosa cells. Endocrinology 142 3590-3597.

Narahara H, Toyoshima K \& Johnston JM 1996 Role of platelet-activating factor in parturition. Advances in Experimental Medicine and Biology 416 269-275.

Newman JW, Watanabe T \& Hammock BD 2002 The simultaneous quantification of cytochrome P450 dependent linoleate and arachidonate metabolites in urine by HPLC-MS/MS. Fournal of Lipid Research 43 1563-1578.

Newman JW, Stok JE, Vidal JD, Corbin CJ, Huang Q, Hammock BD \& Conley AJ 2004 Cytochrome p450-dependent lipid metabolism in preovulatory follicles. Endocrinology 145 5097-5105.

Ohara Y, Peterson TE \& Harrison DG 1993 Hypercholesterolemia increases endothelial superoxide anion production. Fournal of Clinical Investigation 91 2546-2551.

Pate JL \& Condon WA 1989 Regulation of steroidogenesis and cholesterol synthesis by prostaglandin F-2 alpha and lipoproteins in bovine luteal cells. Fournal of Reproduction and Fertility $\mathbf{8 7}$ $439-446$.

Peluso JJ \& Pappalardo A 1998 Progesterone mediates its anti-mitogenic and anti-apoptotic actions in rat granulosa cells through a progesterone-binding protein with gamma aminobutyric acid receptor-like features. Biology of Reproduction 58 1131-1137.

Quirk SM, Cowan RG \& Harman RM 2004 Progesterone receptor and the cell cycle modulate apoptosis in granulosa cells. Endocrinology 145 5033-5043.

Ragoobir J, Abayasekara DR, Bruckdorfer KR \& Michael AE 2002 Stimulation of progesterone production in human granulosa-lutein cells by lipoproteins: evidence for cholesterol-independent actions of high-density lipoproteins. Fournal of Endocrinology 173 103-111.

Reaven E, Nomoto A, Leers-Sucheta S, Temel R, Williams DL \& Azhar S 1998 Expression and microvillar localization of scavenger receptor, class B, type I (a high-density lipoprotein receptor) in luteinized and hormone-desensitized rat ovarian models. Endocrinology 139 2847-2856. 
Robker RL \& Richards JS 1998 Hormonal control of the cell cycle in ovarian cells: proliferation versus differentiation. Biology of Reproduction 59 476-482.

Robker RL, Russell DL, Espey LL, Lydon JP, O’Malley BW \& Richards JS 2000 Progesterone-regulated genes in the ovulation process: ADAMTS-1 and cathepsin L proteases. PNAS 97 4689-4694.

Salari H 1986 Solid-phase extraction and reversed-phase high-performance liquid chromatographic technique for isolation and estimation of platelet activating factor in plasma. Fournal of Chromatography 382 89-98.

Sasano H, Mori T, Sasano N, Nagura H \& Mason JI 1990 Immunolocalization of 3 beta-hydroxysteroid dehydrogenase in human ovary. Fournal of Reproduction and Fertility 89 743-751.

Schneider F, Bellmann A, Becker F, Bambang Poernomo S, Rehfeldt C, Nurnberg G \& Kanitz W 2002 Gonadotropin release in periovulatory heifers after GnRH analogs measured by two types of immunoassays. Experimental and Clinical Endocrinology and Diabetes $110235-244$.

Simpson ER, Rochelle DB, Carr BR \& MacDonald PC 1980 Plasma lipoproteins in follicular fluid of human ovaries. Fournal of Clinical Endocrinology and Metabolism 51 1469-1471.

Sirois J 1994 Induction of prostaglandin endoperoxide synthase-2 by human chorionic gonadotropin in bovine preovulatory follicles in vivo. Endocrinology 135 841-848.

Sirois J, Sayasith K, Brown KA, Stock AE, Bouchard N \& Dore M 2004 Cyclooxygenase-2 and its role in ovulation: a 2004 account. Human Reproduction Update 10 373-385.

Sligar SG, Lipscomb JD, Debrunner PG \& Gunsalus IC 1974 Superoxide anion production by the autoxidation of cytochrome P450 cam. Biochemical and Biophysical Research Communications 61 290-296.

Smith WL, Garavito RM \& DeWitt DL 1996 Prostaglandin endoperoxide $\mathrm{H}$ synthases (cyclooxygenases)-1 and -2. Fournal of Biological Chemistry 271 33157-33160.

Smith WL, DeWitt DL \& Garavito RM 2000 Cyclooxygenases: structural, cellular, and molecular biology. Annual Review of Biochemistry 69 145-182.

Solano AR, Neher R \& Podesta EJ 1984 Rat adrenal cycloheximide-sensitive factors and phospholipids in the control of acute steroidogenesis. Fournal of Steroid Biochemistry and Molecular Biology 21 111-116.

Spector AA, Fang X, Snyder GD \& Weintraub NL 2004 Epoxyeicosatrienoic acids (EETs): metabolism and biochemical function. Progress in Lipid Research 43 55-90.
Tanaka N, Espey LL, Kawano T \& Okamura H 1991 Comparison of inhibitory actions of indomethacin and epostane on ovulation in rats. American Fournal of Physiology 260 E170-E174.

Tian XC, Berndtson AK \& Fortune JE 1995 Differentiation of bovine preovulatory follicles during the follicular phase is associated with increases in messenger ribonucleic acid for cytochrome $\mathrm{P} 450$ side-chain cleavage, 3 beta-hydroxysteroid dehydrogenase, and P450 17 alpha-hydroxylase, but not P450 aromatase. Endocrinology 136 5102-5110.

Tojo H, Ono T, Kuramitsu S, Kagamiyama H \& Okamoto M 1988 A phospholipase A2 in the supernatant fraction of rat spleen. Its similarity to rat pancreatic phospholipase A2. Journal of Biological Chemistry 263 5724-5731.

Tsafriri A \& Reich R 1999 Molecular aspects of mammalian ovulation. Experimental and Clinical Endocrinology and Diabetes 107 $1-11$.

Tsai SJ, Wiltbank MC \& Bodensteiner KJ 1996 Distinct mechanisms regulate induction of messenger ribonucleic acid for prostaglandin (PG) G/H synthase-2, PGE (EP3) receptor, and PGF2 alpha receptor in bovine preovulatory follicles. Endocrinology 137 3348-3355.

Umans L, Overbergh L, Serneels L, Tesseur I \& Van Leuven F 1999 Analysis of expression of genes involved in apolipoprotein E-based lipoprotein metabolism in pregnant mice deficient in the receptor-associated protein, the low density lipoprotein receptor, or apolipoprotein E. Biology of Reproduction 61 1216-1225.

Volpe A, Coukos G, Uccelli E, Droghini F, Adamo R \& Artini PG 1991 Follicular fluid lipoproteins in preovulatory period and their relationship with follicular maturation and progesterone production by human granulosa-luteal cells in vivo and in vitro. Fournal of Endocrinological Investigations 14 737-742.

Voss AK \& Fortune JE 1993 Levels of messenger ribonucleic acid for cytochrome P450 17 alpha-hydroxylase and P450 aromatase in preovulatory bovine follicles decrease after the luteinizing hormone surge. Endocrinology 132 888-894.

Wu YL \& Wiltbank MC 2002 Transcriptional regulation of the cyclooxygenase-2 gene changes from protein kinase (PK) A- to PKC-dependence after luteinization of granulosa cells. Biology of Reproduction 66 1505-1514.

Received 31 August 2005 Accepted 26 September 2005 